\title{
Demolition of Old Oak Bridge B4113: Condition of a 54-year old prestressed concrete bridge
}

\author{
${\text { Wandie } \text { Kramer }^{1 *} \text {, William Martin }}^{1}$, and Harry Viljoen ${ }^{2}$ \\ ${ }^{1}$ SMEC South Africa Consulting Engineers, 65 Riebeek Street, Cape Town, South Africa 8001 \\ ${ }^{2}$ Western Cape Government, Department of Transport \& Public Works, 9 Dorp Street, Cape Town, South Africa 8001
}

\begin{abstract}
The extension of the $3^{\text {rd }}$ lane on Trunk Road 9 Section 1 (N1) at Bellville in the Western Cape necessitated the demolition and replacement of the Old Oak Road Underpass Bridge B4113. This bridge had insufficient vertical clearance as well as insufficient horizontal clearance for the widening of the road. Furthermore, the existing precast beam and slab deck has suffered from repeated vehicular impact damage over the years, resulting in continued costly repairs. This paper describes the condition of this bridge after a 54-year service life. The primary objective is to report and comment on the condition of this bridge in order for other engineers who have to rehabilitate, raise or widen similar bridges built at the same time, to have an indication of the quality of materials, workmanship, condition and behaviour. During and after the demolition operation, a visual inspection of the rubble was undertaken to evaluate the condition of this bridge which was constructed in 1963. Concrete cores taken before the demolition revealed higher concrete strengths of $50 \%$ and more. Carbonation and durability tests done on concrete fragments indicated a robust and durable structure which would easily reach its intended 100-year design life. However, overlays under the bridge reduced the vertical clearance while the expansion joint details led to reduced durability.
\end{abstract}

\section{Introduction}

\subsection{Location of Old Oak Interchange}

Old Oak Interchange in Cape Town is located on Trunk Road 9/1 (TR9/1) at km 18.69, approximately $1 \mathrm{~km}$ west of the R300 Interchange (Fig. 1). It consists of 2 independent bridges with a horizontal clearance between the existing decks of $2.37 \mathrm{~m}$. Bridge B4113 (west side), constructed in 1963, supported the two-lane northbound Old Oak Road over the dual carriageway section of TR9/1. Bridge B5884 (east side), constructed in 1993, supports the three-lane southbound Old Oak Road over the dual carriage way section of TR9/1 (Fig. 2).

\subsection{Old Oak Bridge B4113 - typical details}

The Old Oak Road Underpass Bridge B4113 was constructed in 1963 with the Roads Department of the Cape Provincial Administration as the Owner. In 2017, the measured minimum vertical clearance was $4.74 \mathrm{~m}$. The bridge is a four-span simply-supported structure of $74 \mathrm{~m}$ length with typical span lengths of $18.5 \mathrm{~m}$. The structural form is beam and slab, comprising nine precast prestressed beams per span. Transverse diaphragms were located at quarter points in each span as well as at each support. The deck is supported on reinforced concrete abutments and piers, all founded on spread footings. However, the median pier was founded on piles straddling the $1220 \mathrm{~mm}$ diameter Wemmershoek bulk water-main. The bearing system consisted of laminated elastomeric rubber pads at the piers and abutments.

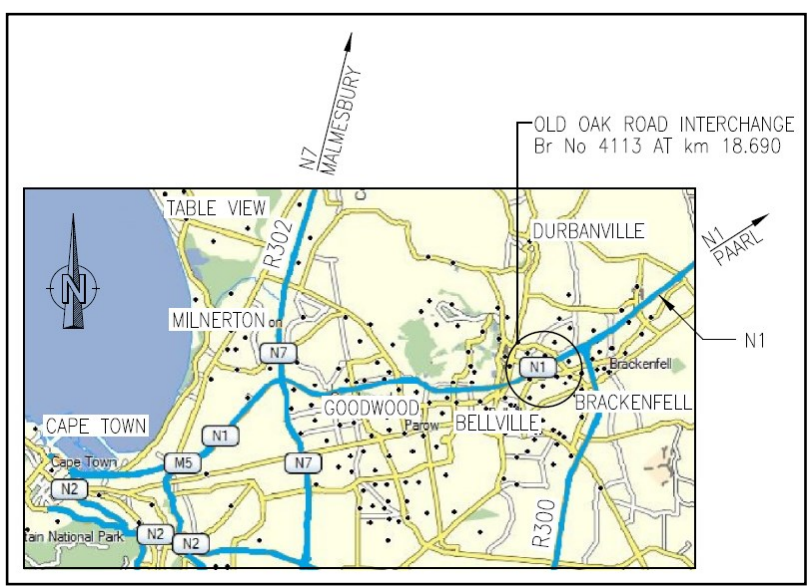

Fig. 1. Locality plan of Old Oak Interchange.

\subsection{Old Oak Bridge B5884 - typical details}

The Old Oak Road Underpass Bridge B5884 was constructed in 1993. Commissioned by the Roads

\footnotetext{
* Corresponding author: wandie.kramer@smec.com
} 
Department of the Cape Provincial Administration, it was built with a minimum vertical clearance of $5.23 \mathrm{~m}$.

The $89.3 \mathrm{~m}$ long four-span bridge has 2 main spans of $24.85 \mathrm{~m}$ each and 2 jack spans of $20.4 \mathrm{~m}$ and $12.08 \mathrm{~m}$. The bridge is on a $11^{\circ}$ skew in plan and has an overall width of $15.3 \mathrm{~m}$. The bridge superstructure comprises a continuous prestressed concrete voided slab deck.

The piers and abutments are founded on $520 \mathrm{~mm}$ diameter piles, ranging from $6 \mathrm{~m}$ to $17.5 \mathrm{~m}$ in length.

\subsection{Motivation for demolition and replacement}

The Old Oak Road Underpass Bridge B4113 spans were not long enough to accept the extension of the $3^{\text {rd }}$ lane on each carriageway of TR9/1 underneath. This bridge also had insufficient vertical clearance for the upgrading of the road. The minimum vertical clearances to the westbound and eastbound carriageways were respectively $460 \mathrm{~mm}$ and $220 \mathrm{~mm}$ less than the $5.2 \mathrm{~m}$ minimum required. This substandard vertical clearance has resulted in severe vehicular impact damage on several occasions to 4 beams over the left lane on the westbound carriageway on the western side of the deck.

After considering various alternatives, the decision was made that the bridge had to be demolished and replaced with one of sufficient vertical and horizontal clearance.

\subsection{Demolition operation}

The demolition operation took place during the weekend of 12 - 14 May 2017. It was a successful operation which saw the bridge demolished and the road re-opened to traffic in just over 22 hours. It took roughly 10 hours to demolish the bridge and then another 12 hours to clear away the concrete debris and the soil blanket on the road and re-erect guardrails. Excavators with pneumatic jackhammers were used to demolish the bridge. This method was preferred over blasting due to the close proximity of Bridge B5884 (see Fig. 2 below).

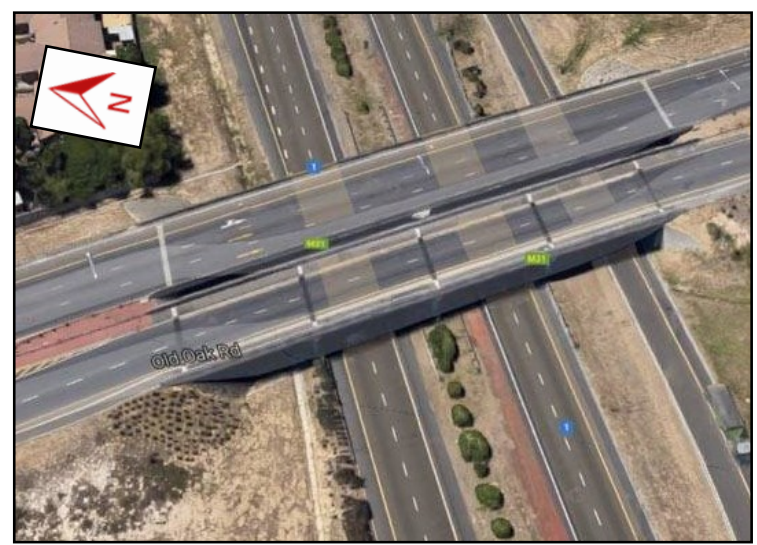

Fig. 2. Aerial view of Old Oak Interchange before demolition (B4113 is the lower bridge in the photo).

This close proximity of the 2 bridges further complicated the demolition insofar as the excavators could only demolish the bridge from one side, potentially increasing the demolition period. The N1 is a vitally important route with an Annual Average Daily Traffic (AADT) of 115000 vehicles in 2013 of which $6 \%$ constitutes heavy vehicles. It carries large traffic volumes and forms a major arterial route for the greater Cape Town area. It was therefore imperative to close the $\mathrm{N} 1$ for the demolition period as short as possible to ensure minimal disruption for travellers.

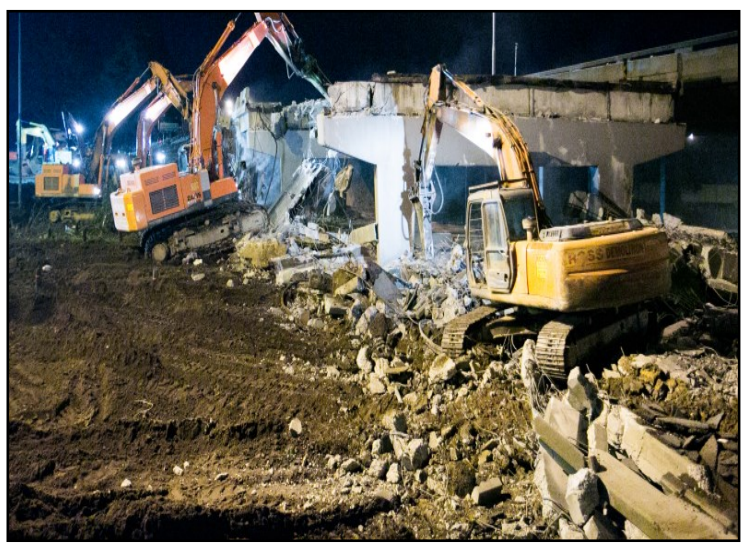

Fig. 3. During the demolition operation.

\section{Condition of Old Oak Bridge B4113}

\subsection{Summary of bridge layout}

Old Oak Interchange's layout in Fig. 4 clearly shows the proximity of the 2 bridges. It also illustrates the difference in bridge B4113's pier 2 and 4 position relative to bridge $\mathrm{B} 5884$.

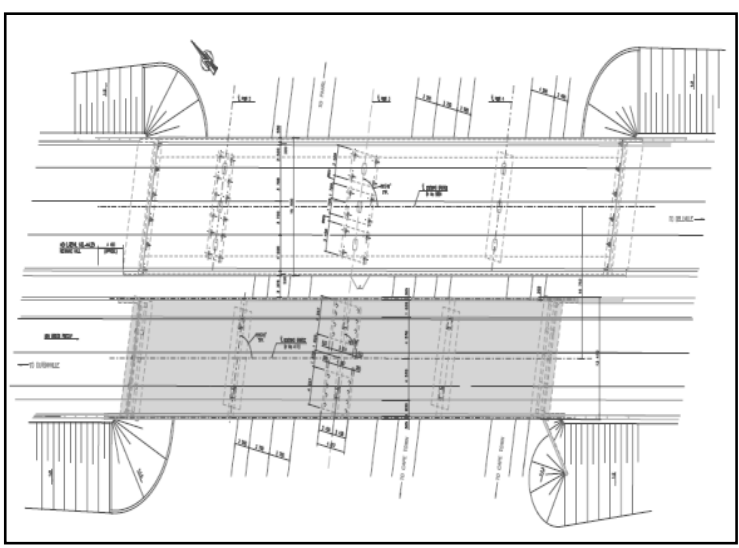

Fig. 4. Layout of Old Oak Interchange.

The piers comprised 2 columns each with a pier-head which supported the 9 precast prestressed beams (Fig. 5).

The abutments were spill-through type columns. Abutment 5 on the south side had to be retrofitted with a soil-nailed reinforced concrete wall to allow a distributor lane to pass underneath the $4^{\text {th }}$ span. These upgrades were done during the construction of bridge B5884 in 1993.

The foundations for all the supports were spread footings, except pier 3 which has piled foundations. There were 16 no. $406 \mathrm{~mm}$ diameter bored in-situ piles straddling the Wemmershoek water-main at pier 3 . The 
typical working load for these existing piles was problematic as their capacity was uncertain. During the design stage, it was decided to incorporate these existing piles into the pile cap of the new bridge, in addition to new piles. As per A Guide to Practical Geotechnical Engineering in Southern Africa the typical working load of these existing piles was assumed to be $750 \mathrm{kN}$ per pile, the equivalent of a $410 \mathrm{~mm}$ Franki Driven Cast-InSitu Pile [1]. During the demolition procedure in May 2017 the existing piles were exposed in order to reconnect them into the new pile cap. Considerable care was taken during the demolition procedure whilst opening up these piles in order to preserve their integrity

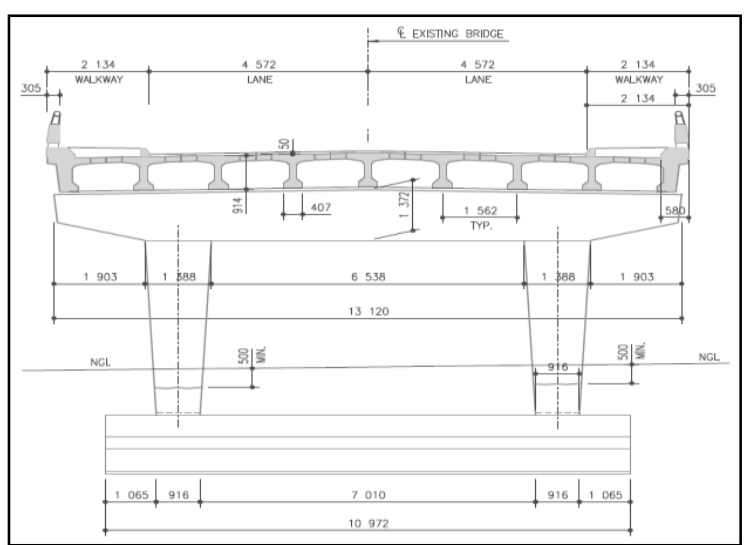

Fig. 5. Cross section through pier 2.

Sonic integrity tests were conducted on 8 of the 16 piles. These tests were performed using a highly sensitive accelerometer and a special purpose Pile Integrity Tester (PIT) with digitising and graphics capabilities. The depths recorded indicate very shallow pile depths (Table 1) and the load bearing capacity initially assumed is therefore in question.

In order to verify the PIT test results, it was decided to core through 2 of the piles to corroborate these shallow depths (Table 1):

Table 1. Existing pile depths at pier 3.

\begin{tabular}{|c|c|c|}
\hline $\begin{array}{c}\text { Pile } \\
\text { number }\end{array}$ & $\begin{array}{c}\text { Depth according to } \\
\text { PIT test } \\
{[\mathrm{m}]}\end{array}$ & $\begin{array}{c}\text { Depth established } \\
\text { through coring } \\
{[\mathrm{m}]}\end{array}$ \\
\hline 1 & 2.66 & 1.85 \\
\hline 2 & 2.96 & - \\
\hline 3 & 3.04 & - \\
\hline 4 & 1.80 & 1.4 \\
\hline 5 & 3.55 & - \\
\hline 6 & 3.05 & - \\
\hline 7 & 2.82 & - \\
\hline 8 & 4.32 & - \\
\hline
\end{tabular}

The piles installed at pier 3 are therefore very shallow and not suitable to carry the presumed working load for a $410 \mathrm{~mm}$ bored in-situ pile, requiring the capacity to be downgraded during design.

\subsection{Vertical clearance}

The measured minimum vertical clearance to the old bridge was $4.74 \mathrm{~m}$. Before 1969, the minimum vertical clearance to road bridges was $4.88 \mathrm{~m}$ (16'-0"). This meant that road surfacing overlays over the years reduced the clearance by $140 \mathrm{~mm}$, making the bridge more prone to impact damage from illegally high vehicles. This illustrates the importance of being very careful in reducing vertical clearance under bridges during road rehabilitation.

Around 1969 the vertical clearance to road bridges was increased to $5.03 \mathrm{~m}\left(16^{\prime}-6^{\prime \prime}\right)$. At about 1979 it was further increased to $5.10 \mathrm{~m}$ then to $5.20 \mathrm{~m}$ around 1988 . These dates varied depending on the road authority.

The legally permissible height limit for a road vehicle is set at $4.3 \mathrm{~m}$ in Regulation 354. Any vehicle higher than this is considered an Abnormal Load and requires an Exemption Permit ("Abnormal Load Permit") to use a public road.

Beam and slab decks have a higher susceptibility to impact damage due to the beams being less robust than more solid deck forms. Because of the long-term implication of successive impacts in terms of loss of serviceability and structural integrity, new beam and slab bridges are constructed with a minimum vertical clearance of $5.6 \mathrm{~m}$. It is noted that, irrespective of the additional clearance, these precast beam and slab bridges tend to suffer damage from vehicular impact. This is evident on other parts of the TR9/1 where bridges with clearances between $5.2 \mathrm{~m}$ and $5.5 \mathrm{~m}$ are struck on a regular basis.

\subsection{Condition of reinforcement}

The reinforcement in the substructure consisted of only mild steel with diameters up to $40 \mathrm{~mm}$. The superstructure consisted of both mild steel and high tensile steel, mostly in small diameters. The high tensile steel can be distinguished from the mild steel by having one thin spiral across the bar (Fig. 6).

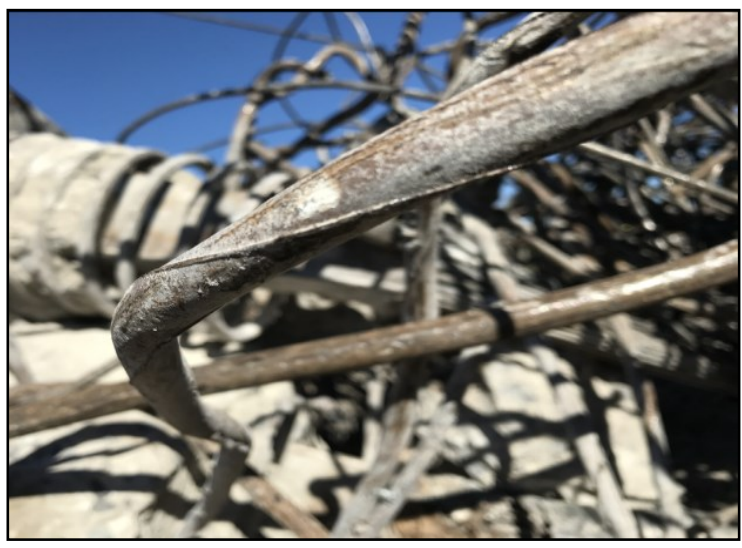

Fig. 6. High tensile steel (note the thin spiral around bar).

The cover to all the main reinforcement is indicated as $40 \mathrm{~mm}$ on the drawings.

The reinforcement is in impeccable condition with hardly any corrosion visible after a 54-year service life: 


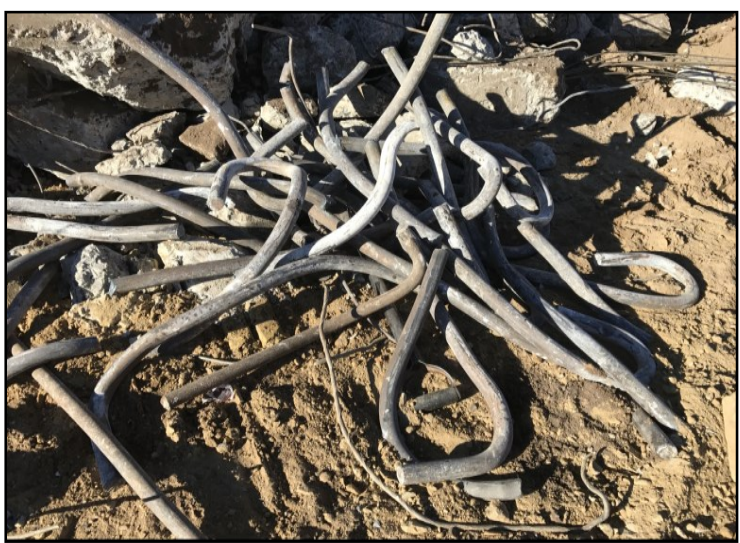

Fig. 7. Bunch of R40's. Notice the absence of corrosion after 54 years.

The reinforcement was imported from England and is of a very high quality. The working stress indicated on the drawings for the high tensile steel is $186 \mathrm{MPa}$ (27000 psi). Tests done on four samples yielded the following results (Table 2) which are significantly higher than the design values:

Table 2. Mechanical test results of reinforcement.

\begin{tabular}{|l|c|c|}
\hline Bar type & Yield strength & $\begin{array}{c}\text { Ultimate } \\
\text { strength }\end{array}$ \\
\hline Mild steel & $329 \mathrm{MPa}$ & $499 \mathrm{MPa}$ \\
\hline High tensile steel & $372 \mathrm{MPa}$ & $557 \mathrm{MPa}$ \\
\hline
\end{tabular}

The amount of reinforcement to be found in the substructure and superstructure for B4113 is presented in Table 3, 4, 5 and 6:

Table 3. Amount of reinforcement in piers (all mild steel).

\begin{tabular}{|c|c|c|}
\hline $\begin{array}{c}\text { Diameter } \\
{[\mathrm{mm}]}\end{array}$ & $\begin{array}{c}\text { Length } \\
{[\mathrm{m}]}\end{array}$ & $\begin{array}{c}\text { Weight } \\
{[\mathrm{t}]}\end{array}$ \\
\hline 10 & 1232 & 0.690 \\
\hline 12 & 1453 & 1.443 \\
\hline 16 & 1672 & 3.050 \\
\hline 22 & 393 & 1.120 \\
\hline 32 & 1257 & 5.100 \\
\hline 40 & 2912 & 9.690 \\
\hline TOTAL & $\mathbf{8 9 1 9}$ & $\mathbf{2 1 . 1 0 0}$ \\
\hline
\end{tabular}

Table 4. Amount of reinforcement in abutments (all mild steel).

\begin{tabular}{|c|c|c|}
\hline $\begin{array}{c}\text { Diameter } \\
{[\mathrm{mm}]}\end{array}$ & $\begin{array}{c}\text { Length } \\
{[\mathrm{m}]}\end{array}$ & $\begin{array}{c}\text { Weight } \\
{[\mathrm{t}]}\end{array}$ \\
\hline 10 & 500 & 0.280 \\
\hline 12 & 3140 & 3.120 \\
\hline 16 & 380 & 0.590 \\
\hline 20 & 520 & 1.160 \\
\hline 25 & 600 & 2.380 \\
\hline 32 & 290 & 1.780 \\
\hline TOTAL & $\mathbf{5 4 3 0}$ & $\mathbf{9 . 3 1 0}$ \\
\hline
\end{tabular}

Table 5. Amount of reinforcement in balustrades (mild steel).

\begin{tabular}{|c|c|c|}
\hline $\begin{array}{c}\text { Diameter } \\
{[\mathrm{mm}]}\end{array}$ & $\begin{array}{c}\text { Length } \\
{[\mathrm{m}]}\end{array}$ & $\begin{array}{c}\text { Weight } \\
{[\mathrm{t}]}\end{array}$ \\
\hline 12 & 260 & 0.480 \\
\hline 20 & 440 & 0.950 \\
\hline TOTAL & $\mathbf{7 0 0}$ & $\mathbf{1 . 4 3 0}$ \\
\hline
\end{tabular}

Table 6. Amount of reinforcement in superstructure (both mild and high tensile steel).

\begin{tabular}{|c|c|c|}
\hline $\begin{array}{c}\text { Diameter } \\
{[\mathrm{mm}]}\end{array}$ & $\begin{array}{c}\text { Length } \\
{[\mathrm{m}]}\end{array}$ & $\begin{array}{c}\text { Weight } \\
{[\mathrm{t}]}\end{array}$ \\
\hline 8 & 1120 & 2.660 \\
\hline 12 & 4740 & 13.640 \\
\hline 16 & 156 & 1.080 \\
\hline 20 & 123 & 0.850 \\
\hline TOTAL & $\mathbf{6 1 4 0}$ & $\mathbf{1 8 . 2 3 0}$ \\
\hline
\end{tabular}

\subsection{Condition of prestressing}

The bridge was stressed longitudinally and transversely. The prestressing in each precast beam, stressed longitudinally, consisted of 2 soft corrugated aluminium ducts with 25 high tensile steel wires per duct. Each wire is $7 \mathrm{~mm}$ in diameter and anchored separately with 2 wedges in a steel cone (Fig. 8).

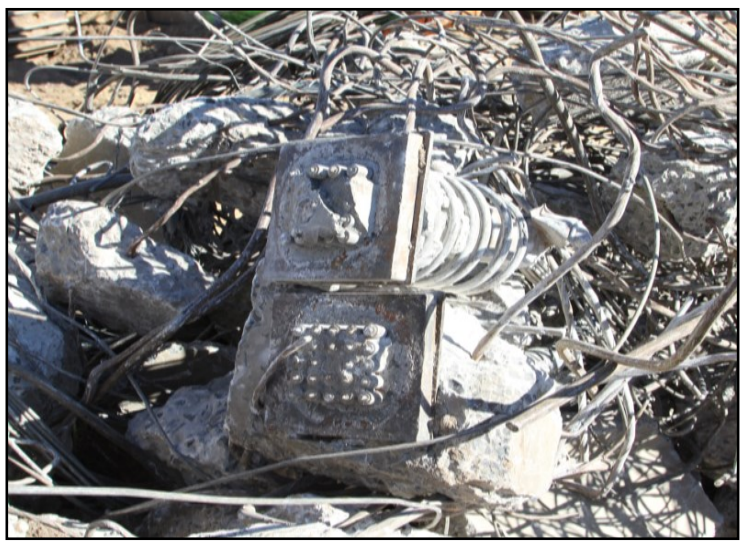

Fig. 8. Anchor blocks displaying prestressing system in precast beams.

The deck was also stressed transversely at the diaphragms. There were 5 diaphragms per span which consisted of 3 intermediate and 2 support diaphragms. Intermediate diaphragms comprised 2 soft corrugated aluminium ducts (Fig. 9) with 8 high tensile steel wires each $7 \mathrm{~mm}$ in diameter. The support diaphragms however, contained 12 high tensile steel wires also $7 \mathrm{~mm}$ in diameter. 


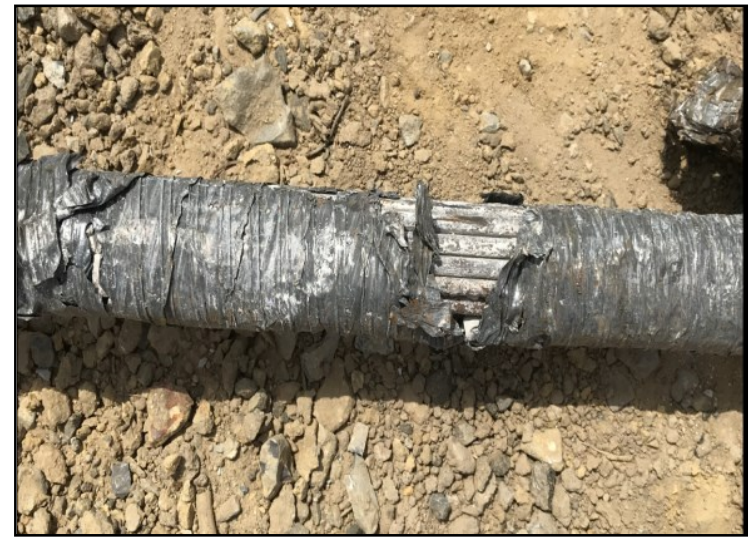

Fig. 9. Corrugated aluminium duct around steel cables.

The prestressing ducts were not fully grouted: grout was only found at the end of each beam.

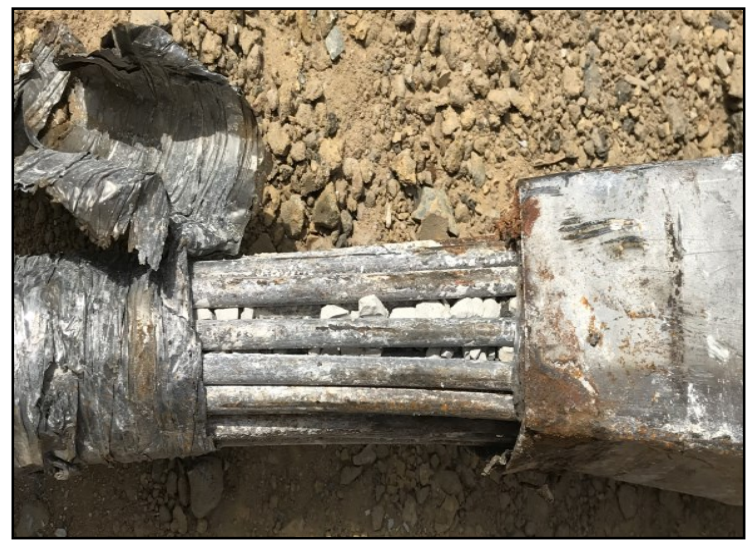

Fig. 10. Grout in prestressing ducts only at the beam's end.

Bridge B4113 was one of the last bridges to be constructed using prestressed wires for prestressing. These wires have been superseded by prestressing strand. The prestressing cables, anchor blocks, wedges and aluminium ducts were in a very good condition when assessed.

One sample of wire was tested giving a yield strength of $1141 \mathrm{MPa}$ which is $74 \%$ of the ultimate strength of $1536 \mathrm{MPa}$. This is quite different to current strand where yield is greater than $80 \%$ of ultimate strength.

\subsection{Compressive strengths: 28 days versus 54 years}

Cylindrical cores were extracted from different bridge elements a week before the demolition. The diameter and length of the cores extracted were both $100 \mathrm{~mm}$, resulting in an aspect ratio of 1 (length to diameter). The core's compressive strength results can therefore be compared to the 28 day cube compressive strength requirement without applying a correction factor to it (Table 7). These were also compared with the expected strength after 54 years.

According to Eurocode, strength gain in concrete with age is $\beta \operatorname{cc}(\mathrm{t})=\exp \left(\mathrm{s}^{*}[1-\operatorname{sqr} t(28 / \mathrm{t})]\right)($ EN1992-1-1: 3.1.2(6)). Assuming the concrete used is equivalent to Class CEM $32.5 \mathrm{~N}$, this will give a strength gain of $44 \%$ from 28 days to 54 years.
As can be seen in Table 7 the concrete strengths for the foundations and piers are well above the design values. For the higher-grade concrete, the difference is much lower with the measured slab strength falling below the expected design strength after 54 years. All measured strengths are well above the 28-day design cube strengths.

Table 7. Compressive strength comparison (length to diameter ratio of cores tested equals 1 ).

\begin{tabular}{|c|c|c|}
\hline & $\begin{array}{c}\text { Design Strength } \\
28 \text { days (54 yrs) } \\
{[\mathrm{MPa}]}\end{array}$ & $\begin{array}{c}\text { Core Strength } \\
54 \text { years } \\
{[\mathrm{MPa}]}\end{array}$ \\
\hline Pier foundation & $18.6(26.8)$ & $\begin{array}{l}47.5 \\
43.5 \\
50.5\end{array}$ \\
\hline Pier column & $20.7(29.8)$ & $\begin{array}{l}36.0 \\
38.5 \\
39.0\end{array}$ \\
\hline Precast beam & $41.4(59.6)$ & $\begin{array}{l}59.0 \\
66.0 \\
61.5\end{array}$ \\
\hline Slab & $41.4(59.6)$ & $\begin{array}{l}56.5 \\
53.0 \\
55.5\end{array}$ \\
\hline
\end{tabular}

Table 8 outlines the characteristics of each of the cores extracted from the bridge.

Table 8. Characteristics of cores.

\begin{tabular}{|c|c|}
\hline $\begin{array}{l}\text { Pier } \\
\text { foundation }\end{array}$ & $\begin{array}{l}\text { 1. Blow-holes visible } \\
\text { 2. Course and fine grains of sand noticeable } \\
\text { 3. Fines - Cape dune sands } \\
\text { 4. Uneven distribution of stone, i.e. over- } \\
\text { sanded } \\
\text { 5. Stone size }-26 \mathrm{~mm} \\
\text { 6. Stone - hornfels } \\
\text { 7. No stone visible in outer } 5-10 \mathrm{~mm} \text { layer } \\
\text { 8. Protective coating painted over the top of } \\
\text { the footing }\end{array}$ \\
\hline $\begin{array}{l}\text { Pier } \\
\text { column }\end{array}$ & $\begin{array}{l}\text { 1. Blow-holes visible } \\
\text { 2. Course and fine grains of sand noticeable } \\
\text { 3. Fines - Cape dune sands } \\
\text { 4. Uneven distribution of stone, i.e. over- } \\
\text { sanded } \\
\text { 5. Stone size }-19 \mathrm{~mm} \& 26 \mathrm{~mm} \\
\text { 6. Stone - hornfels }\end{array}$ \\
\hline $\begin{array}{l}\text { Beam and } \\
\text { slab }\end{array}$ & $\begin{array}{l}\text { 1. Blow-holes visible } \\
\text { 2. Course and fine grains of sand noticeable } \\
\text { 3. Fines - Cape dune sands } \\
\text { 4. Even distribution of stone } \\
\text { 5. Stone size - } 19 \mathrm{~mm} \\
\text { 6. Stone - quartzite. Different colours of } \\
\text { stone visible }\end{array}$ \\
\hline
\end{tabular}

\subsection{Bearing arrangement and fixity}

On the original drawings done in the early 1960's the fixity and bearing size required at each support is as follows: 
Table 9. Bearing summary (Elastomeric bearings).

\begin{tabular}{|c|c|c|}
\hline Support & Fixity & $\begin{array}{c}\text { Size of bearing } \\
{[\mathrm{mm}]}\end{array}$ \\
\hline \multirow{2}{*}{ North abutment } & Fixed & $152 \times 305 \times 13$ \\
\hline $\begin{array}{c}\text { Pier } 3 \text { (center pier) } \\
\text { pier) }\end{array}$ & Free & $210 \times 210 \times 78$ \\
\cline { 2 - 3 } & Fixed & $152 \times 305 \times 13$ \\
\hline \multirow{2}{*}{\begin{tabular}{c} 
Pier 4 (outer pier) \\
\cline { 2 - 3 }
\end{tabular}} & Free & $133 \times 210 \times 78$ \\
\cline { 2 - 3 } & Fixed & $152 \times 305 \times 13$ \\
\hline South abutment & Fixed & $152 \times 305 \times 13$ \\
\hline
\end{tabular}

All the bearings were laminated elastomeric rubber pads at each support. The original bearings were damaged to some extent during the demolition procedure, but still intact (Fig 11 and Fig 12):

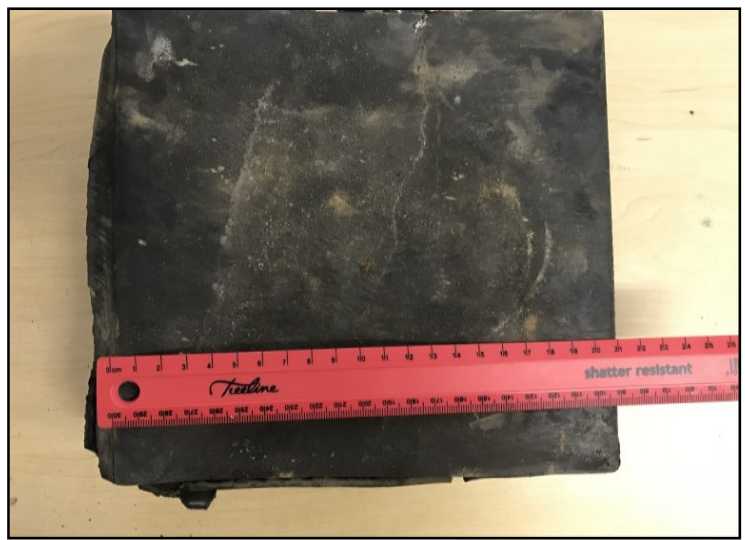

Fig. 11. Original laminated elastomeric bearing salvaged from an outer pier after demolition (dimension $210 \mathrm{~mm}$ ).

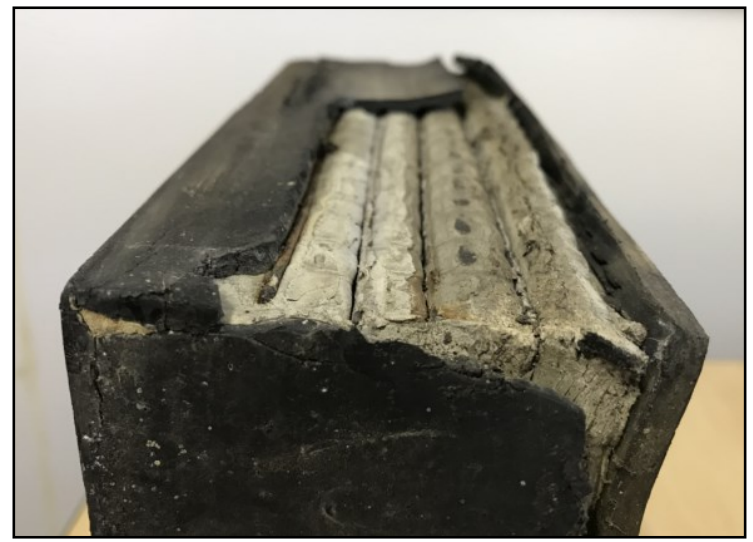

Fig. 12. Original laminated elastomeric bearing salvaged from an outer pier with a partial view of the elastomer and steel plates.
The outside rubber had not deteriorated at all and showed no signs of brittleness. The rubber between the steel plates is in an impeccable condition with very little bulging noticeable only on the edges (Fig. 12). The steel plates are still intact and have not delaminated from the rubber and show no signs of corrosion (Fig 13):

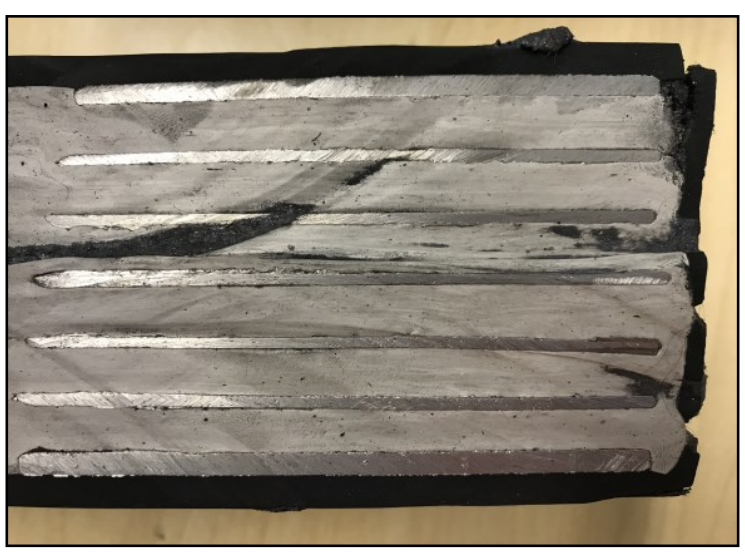

Fig. 13. Bearing cut in half (partial view). No delamination of steel plates to the rubber.

Overall, the original bearings have performed extremely well during their service life of 54 years.

\subsection{Concrete durability - carbonation}

Carbonation, which can lead to the corrosion of reinforcement, is the reaction between atmospheric carbon dioxide and the calcium hydroxide generated in cement hydration. The precipitation of calcium carbonate reduces the $\mathrm{pH}$ level, permeability and porosity of concrete. Nonetheless, carbonation is not necessarily a negative phenomenon as it increases both the compressive and tensile strength of concrete.

However, carbonation and chloride/sulphate ion intrusion are 2 major factors causing the corrosion of steel reinforcement [2]. A high $\mathrm{pH}$ level in concrete protects steel reinforcement from corrosion. This is due to a thin protective layer of stable ferric-oxides on the surface of the steel called the passive protection of reinforcement. As long as the $\mathrm{pH}$ level in concrete is high $(\mathrm{pH}>11)$ this layer is impermeable. Once the carbonation process lowers the $\mathrm{pH}$ level to around 8 to 9 , the passive protective layer around the steel is disrupted and the reinforcement begins to corrode (depassivized state).

According to a study conducted by the CSIR, the $\mathrm{CO}_{2}$ levels in the atmosphere in the Cape area measured $355.6 \mathrm{ppm}(0.036 \%)$ in 1983 and increased to $387 \mathrm{ppm}$ $(0.039 \%)$ in 2013 [3]. Since the construction of the Old Oak Bridge in 1963 the amount of traffic with its resultant carbon dioxide production has steadily increased. The atmospheric carbon dioxide diffuses into the hardened concrete through pores and when carbonation reaction takes place, the alkalinity of the concrete reduces. The development of carbonation can be equated to a rate proportional to the square root of time. Concrete with a low water/cement ratio and permeability can experience a penetration depth of 
approximately $1 \mathrm{~mm}$ after a year and up to $5 \mathrm{~mm}$ for a high water/cement ratio.

One of the tests for carbonation infiltration is a very simple test using a $1 \%$ phenolphthalein solution. The solution is applied to the surface concrete and should remain either colourless or turn purple. A purple surface indicates a $\mathrm{pH}$ above 8.6 if the concrete is still alkaline whereas a colourless surface indicates a carbonated area with a $\mathrm{pH}$ below 8.6.

About 7 hours after the demolition a $1 \%$ phenolphthalein solution was applied on various fragments of the bridge to assess the effect of carbonation. In most instances carbonation ingress up to $10 \mathrm{~mm}$ was the norm, but some sections showed it infiltrating up to $60 \mathrm{~mm}$, especially near expansion joints (Fig 14 - Fig 16).

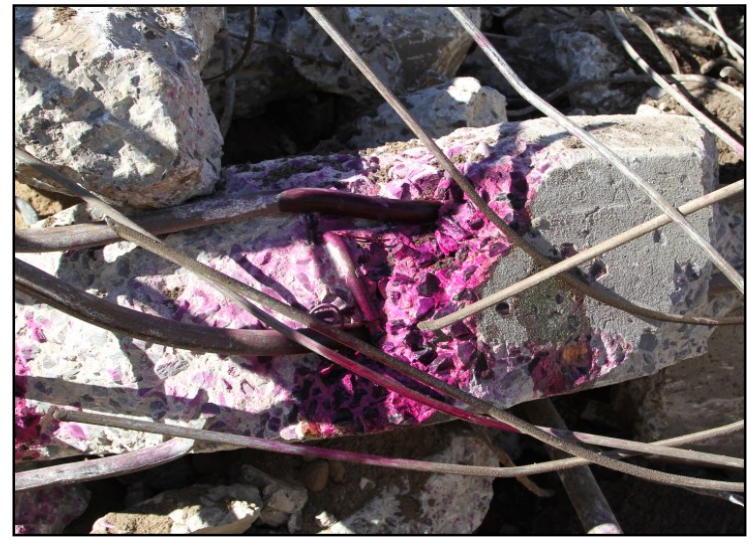

Fig. 14. Carbonation less than $2 \mathrm{~mm}$.

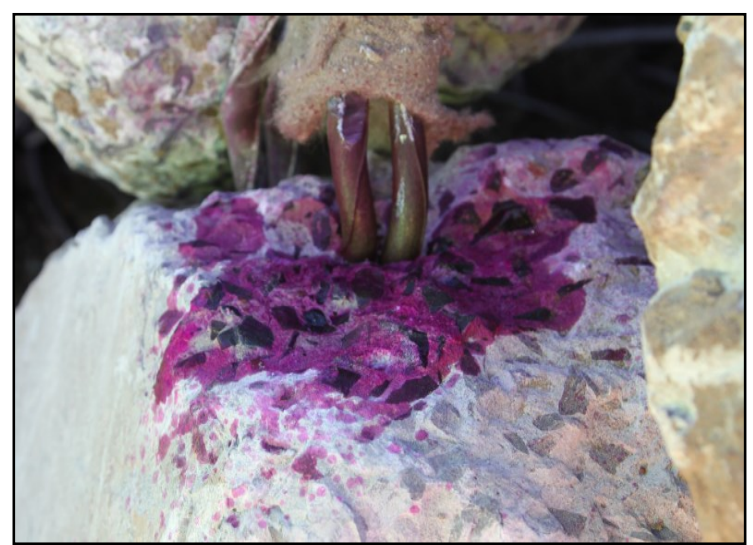

Fig. 15. Carbonation less than $10 \mathrm{~mm}$.

Where the depth of carbonation is about $10 \mathrm{~mm}$ after 54 years, the structure will easily have reached its design life of 100 years without the carbonation front reaching the reinforcement with a $40 \mathrm{~mm}$ concrete cover. However, at areas such as the leaking expansion joints, the depth of carbonation had already reached the reinforcement. Although no significant corrosion was seen on the reinforcement, it is a matter of time before this would have happened with the associated concrete spalling.

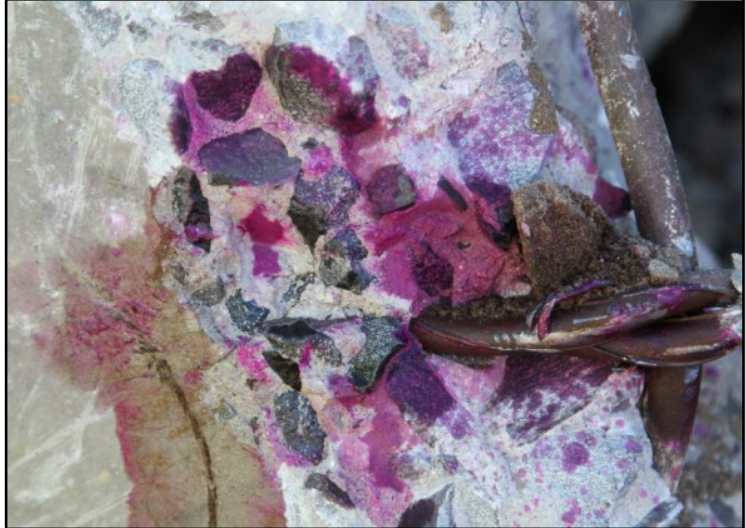

Fig. 16. Carbonation up to $60 \mathrm{~mm}$ near expansion joints.

\subsection{Concrete durability index test methods}

There are 3 durability index test methods commonly performed on concrete, comprising of oxygen permeability, chloride conductivity and water sorptivity. These tests are associated with the transport mechanisms of aggressive agents through hardened concrete. Transport mechanisms such as permeation, diffusion, absorption and migration will cause concrete of low quality to deteriorate more rapidly. A high concrete quality is therefore of utmost importance in order to diminish the deleterious effects of external agents migrating into concrete.

The Oxygen Permeability Index (OPI) test method consists of measuring the pressure decay of oxygen passed through a $30 \mathrm{~mm}$ thick slice of 68 to $70 \mathrm{~mm}$ diameter core of concrete [4]. This test is defined as the negative $\log$ of the coefficient of permeability. In South Africa, common OPI values range between 8.5 to 10.5 . A higher value is indicative of a greater impermeability, indicating a concrete of high quality [4].

An OPI test was conducted on some cores of the demolished bridge. All the results indicated that the concrete is of high quality. The values ranged between 9.64 for the lowest to 10.06 for the highest, with an average of 9.8 for all the results.

The Water Sorptivity Index (WSI) measures the rate of movement of water through the concrete under capillary action. It is a measure of the porosity of the concrete [4]. The sorptivity results of the sample cores ranged between averages of $7.92,9.41$ and $9.75 \mathrm{~mm} / \mathrm{hr}^{0.5}$ and the porosity results ranged between 7.7, 7.8 and 11.0 .

As the bridge is well away from the coast, no tests were done for chloride ingress.

The absence of corrosion to the reinforcement due to carbonation ingress less than $10 \mathrm{~mm}$ in most fragments is indicative of a high quality concrete. It is a robust structure that has shown incredible durability during its 54-years' service life.

\subsection{Repairs during service life}

Bridge B4113 was recently repaired as part of Contract Number C861.1 which ran from November 2010 to December 2011. Major repair items included: 
1. Application of protective coatings to the abutment;

2. Replacement of the asphaltic plug joint at the south abutment;

3. Patch repairs; and

4. Installation of steel protection plates to the flanges of longitudinal beams severely damaged by vehicular impact.

Prior to the repairs undertaken under Contract No. C861.1, vehicle impact damage had occurred on several occasions to 4 beams over the left lane on the westbound carriageway on the western side of the deck. With a minimum clearance of $4.74 \mathrm{~m}$, this might be expected. In 2006 a major repair was carried out to the front beam and minor repairs to the $2^{\text {nd }}, 3^{\text {rd }}$ and $4^{\text {th }}$ beams. Minor repairs were also completed in the 1990's.

Subsequent to these repairs, vehicular impact again damaged the same 4 beams with the outer beam in the area of the previous repair being the worst affected. The impact broke out a relatively large portion of the patch repair material and existing concrete, exposing the prestressing duct and reinforcing. The reinforcement sheared and bent in places although the prestressing duct remained undamaged. Damage to the $2^{\text {nd }}, 3^{\text {rd }}$, and $4^{\text {th }}$ beams were mainly limited to the bottom flanges of the beams.

Under Contract No. C861.1, the beams were repaired and steel protection plates were installed over the full width of the carriageway on the outer and second beams. Due to the need to maintain traffic flow on TR9/1, the plates were installed in 2 separate sections on each beam and welded together on completion, under single lane closures (Fig. 17).

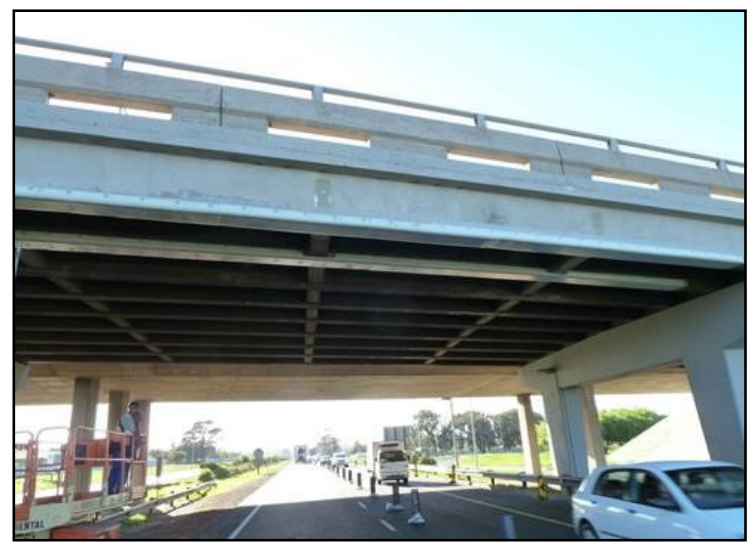

Fig. 17. Steel plate installation (completed July 2011).

At the site inspection undertaken in February 2014 evidence of vehicular impact damage was again noted as shown in Fig. 18 below. The steel protection plates have remained intact with superficial damage to their protective coatings. There was no visible evidence of cracking in the beams which would compromise the strength or durability of the beams.

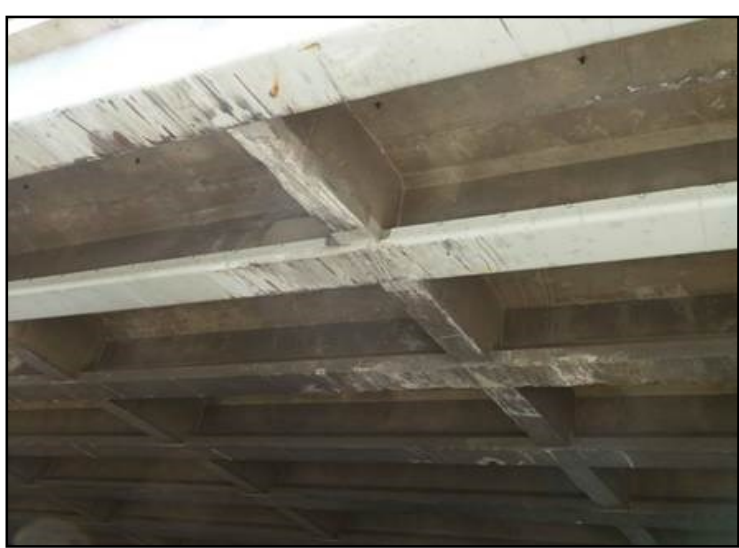

Fig. 18. Impact damage to steel plates (February 2014).

\section{Conclusions}

The widening of TR9/1 in Cape Town required the demolition and replacement of Bridge B4113 at the Old Oak Interchange. The first reason for its demolition is its inadequate vertical clearance. Bridge B4113 suffers impact damage to its soffit regularly. As a matter of fact, during the construction period for the widening of TR9/1 a truck got wedged between the beams. In March 2017, 2 months before its demolition, one of the authors took a photo of this truck trying to get out from between the beams:

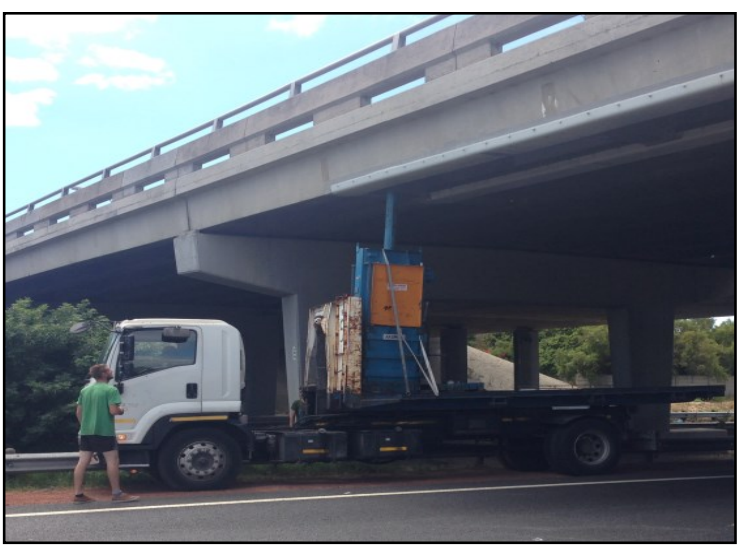

Fig. 19. Truck wedged between beams (notice steel strengthening plates on beams).

The second reason for its demolition is its inadequate horizontal clearance. The outer columns are in the way of the planned extension of a vehicular lane.

Apart from the impact damage, this bridge is still in an impeccable condition after 54-years of service life. The reinforcement is of a high quality with hardly any corrosion. A carbonation assessment on various fragments indicates that the ingress of $\mathrm{CO}_{2}$ has not reached the reinforcement yet, except at the expansion joints. The depths recorded ranged from $2 \mathrm{~mm}$ up to $10 \mathrm{~mm}$ of ingress, except at the expansion joints where carbonation depths reached about $60 \mathrm{~mm}$ after 54 years.

The only durability issue was carbonation reaching the reinforcement at the expansion joints. There is a growing awareness of the importance of maintaining existing expansion joints to ensure longevity. Better 
detailing of expansion joints or elimination of expansion joints will reduce the maintenance requirements and increase the durability of bridges.

Compressive strength tests completed on cores extracted from the bridge a week before the demolition, showed an increase in concrete strengths of $50 \%$ to $80 \%$ on the superstructure. On the substructure the increase in concrete strength was even more substantial with values of $104 \%$ to $200 \%$ and more.

The prestressing ducts, wires and anchor blocks showed no sign of distress and were in a very good condition after the demolition process. Bridge B4113 was one of the last bridges to be constructed using this type of prestressing system, i.e. steel wires, instead of the steel strands which are current practice.

Laminated elastomeric rubber pads were positioned at all the supports. These bearings also showed little deterioration after their 54-year service life.

The assessments presented in this paper confirm that the quality of material and workmanship of Bridge B4113 substantially exceed design requirements. It has endured in a fairly severe environment by being durable and robust and would have reached its 100-year design life with ease. ISO 13823's basic requirement for durability states that a structure shall meet or exceed its design life with acceptable probability. It is a pity that Bridge B4113 had to be demolished in order to make space for more vehicular traffic.
The authors acknowledge the collaborative efforts which helped make this work possible:

1. Client: Western Cape Government, Department of Transport and Public Works;

2. Consulting Engineer: SMEC South Africa (Pty) Ltd;

3. Contractor (civil works): Martin \& East;

4. Contractor (structural works): EMPA Structures;

5. Testing Laboratory (reinforcement): Cape Town Iron and Steel Works;

6. Testing Laboratory (concrete): SGS Matrocast (Pty) Ltd.

\section{References}

1. I.H. Braatvedt, G. Byrne, J.P. Everett, $A$ Guide to Practical Geotechnical Engineering in Southern Africa, $3^{\text {rd }}$ edition (Franki, 1995)

2. R.E. Wilmot, S.A. Inst. of Min. and Met. 107, 139 (2007)

3. L. Butgereit, A. Nickless, 2013 IEEE International Conference, 2013, (2013)

4. Y. Ballim, M.G. Alexander, H. Beushausen. Fulton's Concrete Technology, $9^{\text {th }}$ edition (Cement and Concrete Institute, 2009) 